\title{
From Extremism to Terrorism: Threat Implications of Saffron Terrorism for South Asia
}

\author{
Dr. Qudsia Akram \\ Assistant Professor \\ Department of International Relations \\ Kinnaird College for Women Lahore, Pakistan \\ qudsialakram@hotmail.com \\ Ms. Arusha Siddique \\ Post - Graduate Student \\ Department of International Relations \\ Kinnaird College for Women Lahore, Pakistan
}

\begin{abstract}
The Indian Sub-Continent had two majority religions practiced known as Islam and Hindu, for this the two major ethnicities (Muslims and Hindu's) got independence in the year 1947. The Muslim state that was formed is known as Pakistan and the Hindu state that was formed is called India. Mahatma Gandhi declared that India would be a secular state where all religions will be allowed to practice. However, Rashtriya Swamyamsevak Sangh (RSS) was formed in the year 1925 where the main aim of the party was to have one identity known as Hindu and followed the ideology of Hindutva, It was impossible as India had many different ethnicities in the state, for this the party formed its political (Bhartiya Janata Party) and social wings (Vishwa Hindu Parishad, Bajrang Dal and Shiv Sena etc). Since 2001 Bhartiya Janata Party (BJP) came in power in Gujrat under Narendra Modi the social wing (VHP) started to target Muslim Mosques and even used communal violence as a tool to exploit Muslims due to which Gujrat was known as an Experimental lab where Muslims were targeted economic and socially. The brutality didn't stop as Bhartiya Janata party under Narendra Modi used religion to gain votes and in 2014. However, the extremist ideology became an organized terrorism when Narendra Modi was elected as a Prime Minister of India since then under the ideology of Hindutva. Hindutva is not restricted to India only it has started to become a huge threat for different states in South Asian
\end{abstract}




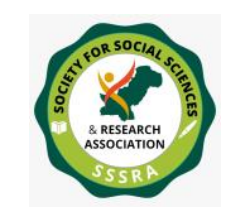

Pak. Journal of Int'L Affairs, Vol 4, Issue 2 (2021)

From Extremism to Terrorism: Threat ...

region such as Bangladesh and Pakistan. Hindutva has become a true example of Saffron extremism and terrorism in India. This research study is based on qualitative research design and would utilize content analysis to understand the transformation of Hindutva into Saffron Terrorism. It would utilize exploratory, historical, and analytical research design to establish that Indian Saffron Terrorism is an emerging issue of contemporary geo-strategic and geo-political design of South Asia.

Key words: Terrorism, Hindutva, Saffron Extremism, South Asia, RSS

\section{INTRODUCTION}

After partition of subcontinent in 1947, Mahatma Gandhi made a statement that India would be a secular state which meant that all religions were to allow to be practiced in the state (India). While India gained independence another issue was about to come in to existence known as Hindutva as Rashtriya Swamyamsevak Sangh (RSS) got inspired by Nazism for that Rashtriya Swamyamsevak Sangh (RSS) made political, social and educational parties. The political wing was formed under Rashtriya Swamyamsevak Sangh (RSS) in the year 1951 followed the ideology of Hindutva known as Bhartiya Jana Sangh (BJS) which had an aim to combine India and Pakistan called as "Akhand Bharat". With the passage of time Bhartiya Jana Sangh (BJS) was resolved in the year 1979 and reorganized itself known as Bhartiya Janata Party (BJP). Today the political wing of Bhartiya Janata Party (BJP) under Narendra Modi is in power.

Bhartiya Janata Party (BJP) party where Narendra Modi came in power in Gujrat as a Chief Minister made a huge issue for Muslims in the state (Gujrat). It can be seen in the past that how the Babri Masjid incident took place in the year 2002. The mosque was sought that it was a birth place of Hindu God Rama due to which it was ordered by Bhartiya Janata Party (BJP) to be destroyed. Many Hindu's gathered with sticks and hammers to demolish the Mosque this movement was known as Ram Janmabhoomi Movement where Bhartiya Janata Party (BJP), Rashtriya Swamyamsevak Sangh (RSS), Shiv Senna and Vishwa Hindu Parishad (VHP) took active role. During the event of Babri Mosque protest was made by Muslims in India (Bombay) and between Indian Police. Police took no harmony on Muslims and attacked Muslim homes, women, restaurants, schools and businesses. These violent attacks on Muslims by Police and by VHP made many issues for Muslims especially in the state of Gujrat due to which many Muslims in the state (Gujrat) got dispersed. These events made many issues for Muslim people due to which it can be observed that it was difficult for them to live in Gujrat with Peace. Since the Babri Mosque issue many Muslim businesses were being destroyed and 


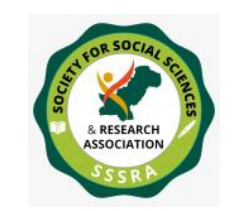

From Extremism to Terrorism: Threat ...

those who were unemployed still remained unemployed. Many Muslims in India faced discrimination such as less no of schools for Muslim students, Hindu students are taught hate against all religions especially Islam and they are being told that Hindu is the prior religion to all other religions, Muslims are not provided with proper health facilities, Muslim have lack of jobs in the state (India) due to which they don't have better living standards, force conversions are being made by Hindu's against Muslims and Muslims are not allowed to celebrate their religious occasions for example Eid-ul-Adha. Since the 9/11 attack it has become easy to attack Muslim minority in India the Prevention of Terrorism Act (POTA) was implemented in the year 2002 where any Muslim who attacks any citizen of state (India) would be charged as "Act of Terrorism" and "Threat to Integrity of the state (India)".

Narendra Modi came in power as Prime Minister of the state (India) in 2014 where he changed the aim from "Akhand Bharat" to "Sanskritik Bharat" which aims cultural Bharat but with the passage of time both of these terms were being resolved. Since the Muslim minority violation was being made in Gujrat only but since Narendra Modi has come to power as Prime Minister the entire state faces minority violation for example Ban for slaughtering or trading of cows and has restrain People to convert in to Muslim or Christian without state's permission. Narendra Modi is being accused for Saffron terrorism in the state (India), this does not end her as Hindutva's implications are being faced internally and externally too where the entire South Asian Region is being facing the implications of Hindutva and this threat is for two major states known as Pakistan and Bangladesh which are Muslim states and share border with India.

Minority has always been an issue in different states due to which the minority always faces issue economic, social and political issues. Minority has always been an issue but in India but this extremism in India has changed in terrorism which is known as Saffron extremism. Bhartiya Janata Party (BJP) under Narendra Modi has been using Saffron terrorism and the term which is being used as a tool which is exploiting not only minorities in India but is also affecting the neighboring South Asian states is called Hindutva.

This research study would focus on Historical factors that gave space for Saffron Terrorism in India, the social disputes, political discourses, economic and religious disparities that further aggravate the minority issue in India. In addition to that it would study the rise of Bhartiya Janata Party (BJP) which led to the rise of Hindutva and its implications in South Asian region. It would tend to answer what are the historical factors that led to Saffron Terrorism in India? the aims of Bhartiya Janata Party (BJP) by using Hindutva against minority in India and the link between Religious radicalization is 


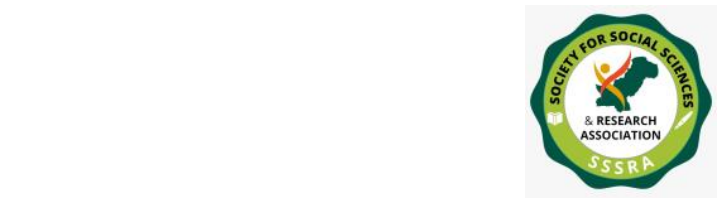

Pak. Journal of Int'L Affairs, Vol 4, Issue 2 (2021)

From Extremism to Terrorism: Threat ...

increasing in Saffron terrorism in India under BJP regime and its implication on South Asian region.

The research design under this research is qualitative research method. The research is based on secondary resources which is available under the premise of the researcher. The data for this research has been collected through Books, Journals, newspaper, different social apps and reports etc.

\section{LITERATURE REVIEW}

According to Ahmed, Modi has strong association with Rashtriya Swamyamsevak Sangh (RSS) and its ideology called Hindutva. Hindutva has influenced in politics and society of the state (India). The history and origin of Hindutva can be traced back in the year 1925 before the independence of the state (India). Hindutva ideology states that before independence of the state (India) invaders subjugated Hindu's which made them a victim. The ideology (Hindutva) even states that Muslim rulers have caused Hindu's a religious suppression and even economic deprivation. The ideology even believes that Hindu's after independence have been united (Ahmed, 2020).

According to Leidig, Hindutva refers in achieving a Hindu state. Hindutva has emerged in to fascist Italy and Nazi Germany. Hindutva is used as instrument in construction of majority of India. Hindutva views violence as a legitimate means of achieving ethnonational territorial claims and the state has, at times, resorted to violent means. And still Hindutva is seen as a truly succeeded mainstream phenomena in 2014 where Narendra Modi was elected as a Prime Minister of India. This has marked Hindu's as insiders and Indian Muslims as outsiders. Narendra Modi has constructed Hindutva with Indian Nationalism (Leidig, 2020).

According to Narula, South Asia as a region has gained a lot significance in the eyes of international community. Most eye catch issue is the rise of Hindu Nationalism, dangerous policies of Bhartiya Janata Party (BJP) and its sister organizations. The policies made by Bhartiya Janata Party (BJP) have resulted violence against Muslims and Christians in the state (India). The violence can be observed from the incident of Babri mosque in the year 2002.This ideology Hindutva is not only effecting Minority in the state (India) whereas it is also effecting the neighboring states and the most effected states are Bangladesh and Pakistan since both are Islamic countries (Narula, 2003).

According to Iqbal, Terrorism mostly focuses over violent extremism by Militant groups which are being related with Islam, whereas the ideology of Hindutva under saffron 


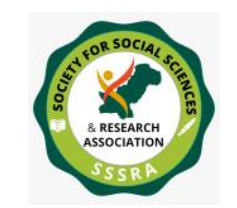

From Extremism to Terrorism: Threat ...

terrorism is being ignored as it has created a threat for Indian Muslims. Since antiPakistan is the part of Hindutva ideology and Pakistan is an Islamic state which automatically turns Indian Muslims to be a part of Pakistan and hate among them is being practiced in the state (India) under the umbrella of political, social and economic violation.

\section{TERRORISM AND STATE}

Terrorism has various definitions because of lack of unanimity over one definition that can include all aspects and dimensions of the word "terrorism". The Definition of terrorism which is used most is given by United Nations (UN) as follow:

"Criminal acts intended or calculated to provoke a state of terror in the general public, a group of persons or particular persons for political purposes are in any circumstance unjustifiable. Whatever the considerations of a political, philosophical, ideological, racial, ethnic, religious or any other nature that may be invoked to justify them." (United Nations General assembly,1994).

It includes three main important points terrorism consists of acts of violence, it has a target audience, it has specific purpose and no justification can be made for its reasoning. Another definition by a well-known scholar, Brian Jenkins states (1985) as:

"Terrorism is defined functionally as a campaign of violence designed to inspire fear, carried out by an organization and devoted to political ends. It is usually characterized by violence against civilian targets in a way to achieve maximum publicity for specific demands, often with the lives of hostages at stake"

Terrorism is defined as use of violence directed towards a large community targeting the civilians of the state. Main short term goals of Terrorism includes as follow:

- Media and public attention

- Destabilizing polity

- Damaging Economies

There are some long term goals of terrorism as well which are as follow:

- Redistribution of power

- Influence and Wealth

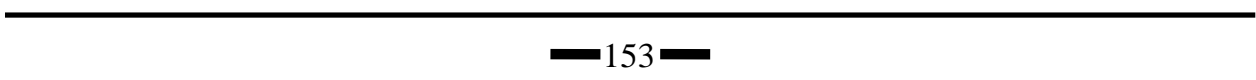




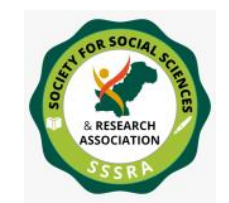

Pak. Journal of Int'L Affairs, Vol 4, Issue 2 (2021)

From Extremism to Terrorism: Threat ...

Terrorists use all above tactics to achieve their goals by using violence. Organizations, group leader influence and some other factors influence the terrorist group behavior as well. The reason why there is no universal definition of terrorism is because freedom fighters, self-determination factor and ethnic cleansing etc most of the times use such violent tactics to achieve their goals. State faces terrorism such as in the case of 9/11 which is known worldwide, Pakistan faces terrorism from Al-Qaeda and Nigeria faces terrorism from Boko Haram etc. Since USA has killed Usama Bin Laden and reduced the number of terrorists, all terrorist organizations for that have made alliance with each other which makes clear that terrorism is not a threat for a state, a region but it's a threat to the whole world which needs to be countered by states under Memorandum of Understanding which will show seriousness and states will have a mutual goal to achieve.

\section{SECULARIZATION AND STATE}

Secularization as institution includes difference of state and Church, some state it as privatization of religious belief and practice and some decline all together of religious belief and practice. But, with modernization of the world the concept has developed a lot today secularization refers to a process which faces religion loses cultural and cultural meaning. Today in modern society the role of religion is restricted. Faith lacks cultural power and even religious organizations have very less power. Secularization is a long term societal change but it costs for the religion itself. It was the Christian tradition which made secularization conceivable by the people where it can be seen that the word God has been removed from the Western people's ordinary life. It was Christian conscience that began to make Europe secular by allowing many religions or by no religion in the state. Religion became one institution among all operating in its own specific area. Once society is defined secular religion becomes plural and rationalization takes hold. Secularization gets institutional support for example separating state and Church (Secularization, Sociology. Emory edu).

Moving towards the concept of secularization and state, many states have adopted the concept of secularization where they allow different religions to be practiced such as Canada which is a great example of secularization where the state allows people to practice their religion according to their choice. Civilians are treated equally under the law whereas moving towards India where Mahatma Gandhi stated that India will be a secular state where it will have religious tolerance but it cannot be observed today as many Muslims and Christians in the state are discriminated such as lack of equal opportunities and lack of resources and sanitation system etc. The concept of secularization is adopted by different states but they are adopted at a certain level and in developing states it just exists as a concept and is not practically implemented. 


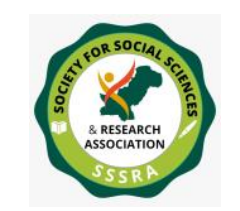

Pak. Journal of Int'L Affairs, Vol 4, Issue 2 (2021)

From Extremism to Terrorism: Threat ...

\section{EXTREMISM AND TERRORISM}

Extremism holds a rigid uttermost and extreme belief or ideology. If not all but some religious traditions and ideologies are constructed through an intermediate or an extreme narrative of the belief. Adhering to the extreme version leads to extremism. It can be associated with any belief system but often linked with religious ideology. The similarities in extremism and terrorism can be found in the evaluation of psychology and ideology of terrorists. The overlap in terrorism and extremism when the question arises about the aspirations and motivations behind the acts of terror. Act of terror is itself extremist incentive because of their non-combatants precision target. They are convinced that only way forward and way to get their demands accepted is to kill innocents is extreme view on religion, self -determination etc. Not all extremists are terrorists and not all terrorists are extremists. Latter point can be understood through the examples of the secessionist movement in Ireland or the National liberation front in Algeria. The right to self- determination in both cases provided them entitlement to commit an act of terrorism because absence of peaceful means to assert their demands. There is a slight difference between Terrorism and extremism since both use the tool of violence.

\section{ORIGIN OF SAFFRON EXTREMISM IN INDIA}

Hindutva has defined the religious boundaries as national boundaries and consider other religions: Christians and Muslims as illegitimate part of Hindu nation. For this purpose to construct the Hindu nation Rashtriya Swamyamsevak Sangh (RSS) Hindu nationalist association was created in year 1925 which was founded by the upper-caste Brahmin Keshav Hedgewar. Its main purpose was to revoke Hindu customs and the two key foundational believes of Hindu nationalism: Sangathan (Hindu organization) and Seva (service). Rashtriya Swamyamsevak Sangh (RSS) activists worked to promote "Hindu nationalism" to the Hindu's of India.

Rashtriya Swamyamsevak Sangh (RSS) is accused for communal violence and terrorism against Muslims and Christians. Currently Rashtriya Swamyamsevak Sangh (RSS) can be seen connected to Indian politics through its political wing known as Bhartiya Janata Party (BJP) (Alder, 2016).

Birth of Bhartiya Jana Sangh (BJS) In the year 1948 Mahatma Gandhi was shot dead by a Hindu nationalist accusing Gandhi of indulging to Muslims. After this major incident Hindu nationalism has advanced along with political mission. In 1951 Bhartiya Jana Sangh (BJS) was established as the political wing of Rashtriya Swamyamsevak Sangh (RSS) by Shyama Prasad Mukherjee (Frayer, 2019). Rashtriya Swamyamsevak Sangh 


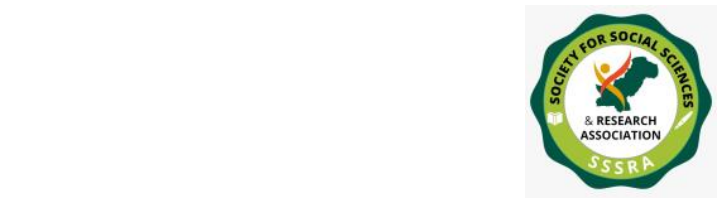

Pak. Journal of Int'L Affairs, Vol 4, Issue 2 (2021)

From Extremism to Terrorism: Threat ...

(RSS) in 1970s was involved in campaigns against Congress Party as it followed secularism which ultimately widened RSS's base within political arena. In the year 1965 Bhartiya Jana Sangh (BJS) passed a resolution known as "Akhand Bharat" which means unifying India and Pakistan. Elections and political parties were considered important spheres through which Hindu nationalists can spread their views. Bharatiya Jana Sangh's (BJS) main ideology was to rebuild India according to the Hindu culture and create a Hindu unity within India. In the year 1967 Bhartiya Jana Sangh (BJS) gained a lot of success in the regions with majorly Hindi-speaking population. In 1977 Atal Bihari Vajpayee led the Bhartiya Jana Sangh (BJS) and joined three other parties to form Janata Party. But, in 1979 the government collapsed, Janata Party separated and in 1980 Bhartiya Janata Party (BJP) was officially formed. The Bhartiya Jana Sangh (BJS) subsequently reorganized itself as the Bhartiya Janata Party (Britannica, 2021).

Bhartiya Janata Party (BJP) Hindutva ideology of Rashtriya Swamyamsevak Sangh (RSS) was advocated by Bhartiya Janata Party (BJP). The Bhartiya Janata Party started to have electoral success in 1989, the party took advantage of Anti-Muslim feeling by stating Babri Masjid (Mosque of Bābur) birth place of God (Hindu God Rama) and stated to build a Hindu temple by demolishing Babri Masjid (Mosque of Bābur). The temple campaign was started by Vishwa Hindu Parishad (VHP) (Social wing of RSS) known as “Ram Janmabhoomi Movement”. Mosque was destroyed in 1992 where BJP, VHP, RSS and Shiv Senna asked for the building of Temple at Babri Mosque this was done to accomplish Hindu rule over India and this shows the Extremism of the party against Muslims. There were 150,000 people who used hammers and axes to rubble the Mosque under this situation the police did not dare to intervene. The incident was a huge violence act made in India which got international coverage as well where seventeen hundred people were killed, thousands were being injured and many women were being raped, majorly including Muslims. To ease fright among the community, to restore selfconfidence in the party and to increase Bhartiya Janata Party's leaders the party undertook a series of 'rath yatras' (journeys on the carriage) known as political marches in which the Hindu God Rama was symbolically raised as the symbol of cultural renaissance (Britanica, 2019). The major affect can be seen in Bombay when there was a violence among Muslims and Indian police the protest made by Muslims was for Babri Mosque, this protest prolonged for straight Ten days. Police fired the Muslim protestors, entered their homes, killed residents and burned their homes as well (Smita Narula, 2003). After so much violence made in India "The Siri Krishna Commission" (investigating the cause of Bombay Riots its victims and witnesses) was being formed in response to violence made in Bombay. The commission presented the report to the government of Maharashtra in the year 1998 after five years of violence made against 


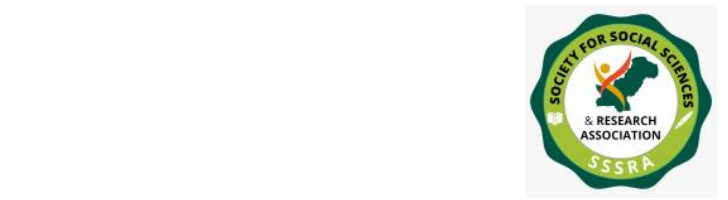

Pak. Journal of Int'L Affairs, Vol 4, Issue 2 (2021)

From Extremism to Terrorism: Threat ...

Muslims. The government refused to adopt all such recommendations and labeled the report "Anti-Hindu".

In the year 1996 Bhartiya Janata Party (BJP) emerged as the largest party in Lok Sabha. In 1998 the Bhartiya Janata Party (BJP) and its allies were able to form a majority government with Vajpayee as prime minister. After 13 months in office, coalition partner All India Dravidian Progressive Federation (All India Anna Dravida Munnetra Kazagham) withdrew its support and Vajpayee lost the Vote of Confidence. Bhartiya Janata Party (BJP) again contested in 1999 elections with the coalition of more than 20 national and regional parties. This alliance secured a majority needed to form a government, Bhartiya Janata Party (BJP) won 182 votes and with coalition it became 294 seats. Vajpayee as leader of the largest party in alliance was again elected prime minister. Muslim victims are being denied of equal protection of Law and equal treatment as citizens of Indian Nation. Bhartiya Janata Party (BJP) made many Muslims to shift to different states. In the year 2003 the Muslim victims filed case against violence but the lawyers started to lose faith as justice was not being given to them when Bhartiya Janata Party (BJP) was in power (The Marginalized Status of Muslim in Gujrat, 2004).

Teaching Hate Bhonsala Militant School which serves as a backbone of the militant Hindutva. The school was made in the year 1930. It is a specialized training school for preparing Hindu Youth. Vishwa Hindu Parshad (VHP) has created a specialized women wing for military style combat training to radical Hindu women in India, the wing is known as Durga Vahni (The army of Durga). Anti-Pakistani sentiments are added in its teaching for example "Hindustan is for Hindus Pakistan can go to hell". Hindu Swabhiman made a holy army which included fifteen thousand soldiers whose aim is to fight against Islamic state. Hindu Swabhiman has made up to hundreds of training camps in different areas of states. This shows that how Saffron extremism is increasing in the state (India) day by day.

Anti-Hindu Sentiments One of the biggest achievements that India thinks that it has rearranged Indian identity as state for Hindu's. Other religions such as Christianity and Muslims are the foreign invaders whose contemporary followers must pay for often constructed sins of their forefathers.

Since the 9/11 attack India has been targeting Muslim minority in the name of "Global War against Terrorism' this has become very easy to reduce the number of Muslim minority in India, for this government had used Prevention of Terrorism Act (POTA) given in the year 2002. Muslims who killed Hindus were charged under POTA these Muslims did not face the same charges as civilians they were treated as terrorists and the 


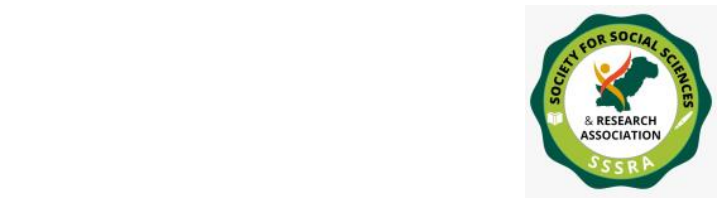

From Extremism to Terrorism: Threat ...

message was clear that any attack against Hindu civilian are actions of terrorists and a clear threat to integrity of the state. Economic boycotts, violence, and gang rape of Muslims in the name of revenging Hindu deaths are believed as justified acts of patriotic Indians responding to a terrorist threat. Muslims faced lack of sanitation and drinking water which caused several health issues more over they were not provided equal health care as Hindu Civilians. Muslims suffered from unemployment and they were restricted towards access of schools etc. After the incident of Gujrat Riot 2002, 297 Mosques have been destroyed (Major attack in India, 2008).

In the year 2006 Gujrat Freedom of Religion Bill was passed where they violated the article 25 and 15 of the constitution where the court prohibited conversion in Islam and Christianity without the permission of the state but allowed the conversion in Buddhism and Jainism as they were a part of Hinduism which shows hatred of Bhartiya Janata Party (BJP) for the religion Islam. In the year 2010 Indian courts have divided the Holy site and stated that the state has weakened the legal system of India for this 200,000 police men have been placed at the site (Babri Mosque) so that public remains calm (Timeline of riots in Modi's Gujrat,2019).

\section{RISE OF HINDUTVA AND BHARTIYA JANATA PARTY (BJP)}

In the year 2014 Lok Sabha elections came close and Bhartiya Janata Party's (BJP) luck began to rise because of growing dissatisfaction with Congress Party rule in India. Narendra Modi the longtime chief minister (head of government) of Gujarat state was chosen to lead the Bhartiya Janata Party (BJP) electoral campaign by making him the party's candidate for prime minister. Bhartiya Janata Party (BJP) won with a clear majority. Modi became prime minister of India on May $26^{\text {th }}$, 2014. Before Modi coming to power in 2012 he stated that Akhand Bharat does not mean to wage war on any state but without war and political consent it can happen and he called it as Sanskritik Bharat (Cultural Bharat). The idea of Akhand Bharat and Sanskritik Bharat was resolved as it was sought that combining India and Pakistan will increase the number of Muslims so, they discarded this goal altogether.

Modi and Hindutva Ideology Rashtriya Swayamsevak Sangh (RSS) and the ideology of Hindutva gained more control in the Indian politics during Modi's reign the reasons are as follow:

- Modi has his own aggressive personality cult

- Anti-Muslims and Anti-Pakistani sentiments

- Radicalization 


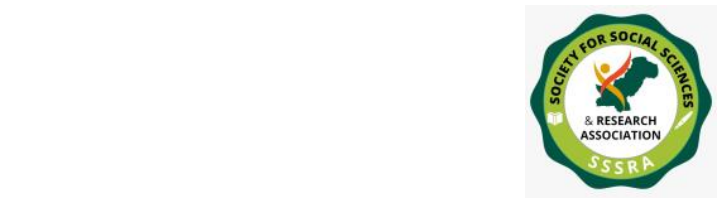

Pak. Journal of Int'L Affairs, Vol 4, Issue 2 (2021)

From Extremism to Terrorism: Threat ...

- Jingoistic nationalism (Rashid, 2020).

In the year 2013 court rejected a petition to prosecute Modi which was filed by a widow of Mr. Jafri who was killed in 2002 riot. The court stated that the widow of Mr. Jafri didn't have enough proofs that Modi has done such act of violence. Since Modi has become the $14^{\text {th }}$ Prime Minister of India there have been increased cases violence against minority. This shows the rise of Saffron extremism in India.

India has the law for the protection of cow in the state where the violation of the law made Muslims and Christians face great issue as Indians that strictly follow their religion and have a practice that they will kill those people to death if they see any individual trading or slaughtering cow because cow is sacred to them. The case gets crueler when a Muslims were caught red-handed by Hindu people. Between the year 2015 -2018 there have been many attacks against Christians and Muslims and Bhartiya Janata Party (BJP0 justifies it. Bhartiya Janata Party (BJP) political leader (Modi) talks about the Hindu culture due to which majority of Hindu support him, as religion is a very sensitive issue and people get attracted to it easily, people have emotional feeling towards their religion and hope for the eternal peace by following it. In the year 2018 Mohan Bhagwat (RSS) stated that he can make six million radicals instantly mobilized faster than Indian army.

Today the ruling part Bhartiya Janata Party (BJP) refuses to accept saffron extremism and has termed such suggestion anti- Indian. In 2019 congress spokesman stated neither its Rahul Gandhi nor any other functional party its "saffron terror" Bhartiya Janata Party has been successful in stating Congress as Anti-Hindu.

\section{HINDUTVA AND SECURITY IMPLICATIONS FOR SOUTH ASIAN STATES}

Hindutva is termed as Hindu Nationalism due to which the violence is made beyond borders of India. Under international human rights law and Indian Constitution the government has the duty to protect Minorities of the state and people who make communal violence against them the government should punish to stop them and intervene. India as a state openly declares that India is a secular democratic; this basically ensures all citizens to liberty of thought, expression, belief, faith and worship. Under the Indian concept of secularism equal rights for all regardless of religion, the exercise of religious freedom and tolerance and rejection of discrimination based on belief.

Pakistan In Pakistan after Babri Mosque incident Blasphemy Laws were continued to occur in Pakistan by religious minorities. For example in 2002 a twenty-six year old man was sentenced to death because of writing hate letters about PBUH. Any pro-Muslims or pro-Pakistani sentiments are technically justifiable for India as they see them as against 


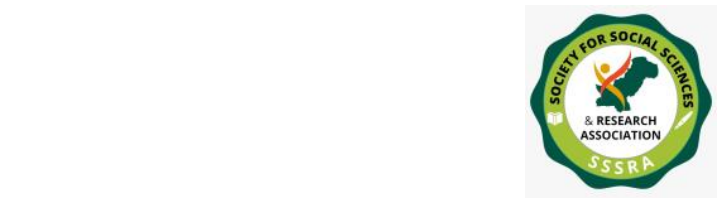

Pak. Journal of Int'L Affairs, Vol 4, Issue 2 (2021)

From Extremism to Terrorism: Threat ...

Hindutva. Hindutva can play a threat to the state (Pakistan) internally and it cannot be denied. It should be remembered that Pakistan may not be at war with Hindutva but Hindutva is at war with Pakistan (CSCR, 2016). Since Hindutva is a threat for Pakistan it should be noticed that it is the state (Pakistan) which is standing as a challenger in the way of India to become regional South Asian hegemon for that India can clearly use Saffron extremism to weaken the state internally for that Pakistan needs to be aware that such issues should not be created as it will affect the economy and it will also make India hegemon in South Asian region (The Nation,2021)

Bangladesh In Bangladesh Hindu community was being attacked when Babri Mosque issue was active. Bangladesh was a state that rejected Islam at the basis of statehood but it had started to drop its secular identifications. In 2001 the general elections were held which made Bangladesh National Party to power in coalition with Islamic Parties and today state implicates strict Islamic Sharia Law. It is stated that Islamic parties after coming in power started looting Hindu homes, burned Hindu temples, sacred sites of Hindu's were destroyed and women and girls were being raped. Many Hindus in Bangladesh started to move towards India for protection of their lives. Hindu people's lands were taken from them due to which they had very less earning. It is stated that 5.3 million Hindus have flew India after so much violence was created against them.

Nepal The state which has $4 \%$ of the Muslim population, have lived peacefully alongside the majority Hindu population for centuries. Nepal as a state has a pride for religious tolerance. India by taking the advantage of Corona Virus situation are pushing hatred in Nepal for Muslim population in the state through their social media. India wants Nepal to declare itself a Hindu country again. In 2006 Nepal became secular. To create hatred among Nepal for Muslims and to spread Hindutva in the region on $10^{\text {th }}$ April, 2021 many Indian News channels stated that Pakistan might have sent Coronavirus-infected Muslim men to India via Nepal. Nepal Government states that it was a fake news but still India made sure to portray it as truth for that both India and Nepal sealed their borders on $30^{\text {th }}$ March, Large number of Nepal civilians and Indian Migrants were quarantined at the border. This shows that how India is eager to spread Hindutva.

The Constitution of India still states that it follows secularism, but for the past thirty years it is moving towards Hindu nationalism. Nehru's commitment to secularism was his declaration that India would be a nonviolent and multi-religious state. Jinnah maintained his doubts which tend to be correct. 


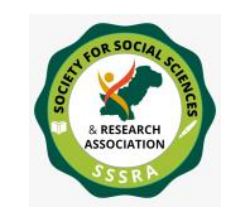

Pak. Journal of Int'L Affairs, Vol 4, Issue 2 (2021)

From Extremism to Terrorism: Threat ...

\section{CONCLUSION}

Extremism is the issue which states are facing since many years and this still exists in the contemporary era. Under extremism the state is usually divided in to different ethnicities, casts and color etc. Religion is sacred to people as they have emotional sentiments and are always ready to fight in the name of it (religion). South Asia is a region which has different languages, casts and ethnicities etc. Before independence these ethnically divided people in South Asia were living to gather under Mughal Empire and British Raj. Pakistan is a state which got independence in the name of religion. Under such circumstances two states (India and Pakistan) got independence where India was the state which had majority of Hindu population and Pakistan was the state which had majority of Muslim population. Mahatma Gandhi stated that India would be a secular state where all religions will be allowed to practice. India is the state which has different religious ethnicities and under the current circumstances it can be observed that India is not following the constitution of the state (India) at all. India has minority population such as Muslims, Christians and Sikhs etc. These Minorities are facing extremism but under Bhartiya Janata Party (BJP) this (extremism) has changed in to Saffron Terrorism in the name of Hindutva. The research paper has described that how Hindutva as a political molded religious concept has made the lives hell of Muslim Minorities in the state (India) and how Hindutva has affected India's neigbouring states as well.

Rashtriya Swamyamsevak Sangh (RSS) Hindu nationalist association was created in year 1925 which was founded by the upper-caste Brahmin Keshav Hedgewar. Its main purpose was to revoke Hindu customs and Hindu nationalism. In 1951 Bhartiya Jana Sangh (BJS) was established as the political wing of Rashtriya Swamyamsevak Sangh (RSS) by Shyama Prasad Mukherjee. Bharatiya Jana Sangh's (BJS) main ideology was to rebuild India according to the Hindu culture and to create Hindu unity within India. Till the year 1967 Bhartiya Jana Sangh (BJS) gained a lot success but in the year 1979 the party collapsed and in the year 1980 Bhartiya Janata Party (BJP) was formed. This party (Bhartiya Janata Party) followed Hindutva as well and got electoral success in the year 1989, under such circumstances the Vishwa Hindu Parishad (VHP) (Social wing of RSS) made an Anti-Muslim movement called known as Ram Janmabhoomi Movement. Under Ram Janmabhoomi Movement (1992) Babri Mosque was destroyed where the social wings and political wing of RSS took part in it actively. It is a known fact that people are emotionally attached to their religion for that Muslims in India (Bombay) made protest where it lasted for ten days straight. The protest made by Muslims in India got a disastrous reaction from Indian Police as police burnt Muslim houses, restaurants, markets and many Muslim women were being raped.

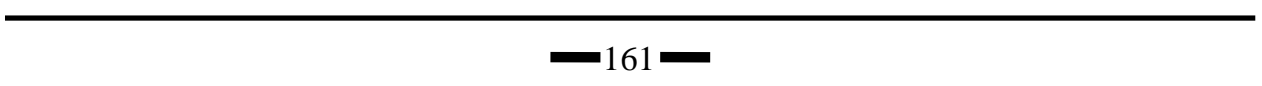




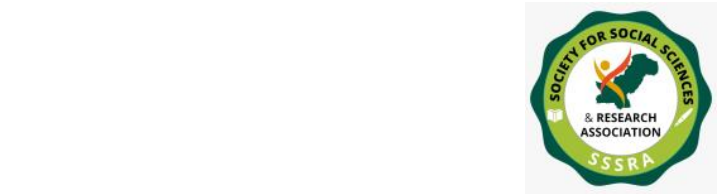

Modi was serving as a Chief Minister of Gujrat from the year 2001. He had Anti-Muslim sentiments and Gujrat was known as an experimental lab against Muslims. Under such situation many Muslims got dispersed from Gujrat. Again the luck of Bhartiya Party (BJP) began to rise and Modi was chosen as a candidate for prime minister. The party (BJP) won with majority votes and Narendra Modi became the Prime Minister of India in 2014. Muslims in India are facing Communal violence due to their religion such as force conversions, Muslim women rape, lack of jobs, lack of sanitation, lack of educational institutes, After Babri Mosque incident Muslim businesses in India were being destroyed, Lack of health care services, religious practices are being forbidden for example Eid-UlAdha where cow slaughter is forbidden as Cow is sacred to Hindu's , no one is allowed to convert themselves from Hindu to Muslim religion, Hindu Children are taught hate against all religions where Hindu religion is superior only and since the 9/11 attack Muslims in India are seen as terrorists as it is stated that any attack on Hindu's by Muslims are terrorist attack under Prevention of Terrorism Act (POTA) which shows that Muslims cannot even defend themselves and state isn't giving them any protection or right moreover the action Muslims take to protect themselves is seen as a terrorist act.

Since Hindutva is on rise in India under Bhartiya Janata Party (BJP) led by Narendra Modi it can be observed clearly that Hindutva has become a threat for India's neigbouring states as well. India and Pakistan have conflict among each other since 1947, Hindu's in Pakistan also act against the Pakistani Government for that Blasphemy laws are increasing in the state (Pakistan) for the love and affection of Hindu religion. Pakistan stands as challenge for India for that India can clearly use saffron terrorism in Pakistan to weaken the state (Pakistan) internally. Since the Babri mosque incident Hindu's in Bangladesh were being attacked for that many Hindu's in the state (Bangladesh) moved to India to save their lives which shows that how people are having religious sentiments this has not affected the state (Bangladesh) only but has also effected the relations between India and Bangladesh. Bangladesh after independence made itself a secular state but since Babri Mosque incident Bangladesh has become an Islamic state. There are other states such as Bhutan and Nepal etc they follow Jainism and Buddhism etc these religions are almost same as Hindu religion for that they don't see Hindutva as a threat instead they see as an opportunity to make diplomatic relations with India (Nuclear power state).

\section{RECOMMENDATIONS}

The research has some recommendations for reducing the threat of Saffron terrorism within India and its implications on South Asian region: 
- India should provide academic freedom and false history should be amended as during the time period of Mughal empire all religions were allowed to be practiced including Hindu religion and under British Raj all religious ethnicities faced violence it was not only Hindu who faced violence.

- Hindu educational institutes should stop teaching that Hindu religion is superior then all other religions as this is reducing the religious tolerance. Respect for all religions should be taught to make the state (India) a better place for everyone.

- Equal opportunities should be provided to all civilians (Opportunities related jobs and education etc).

- The true meaning of Hindu religion should be taught and awareness should be made as Hindutva is a political ideology of which Hindu's think as religion

- The neigbouring states of India should make sure that minority must get the equal rights so that they may not react to any happenings (Such as after Babri Mosque incident many Hindu's in Pakistan were involved in violating Blasphemy law) occurring in India.

- Neighboring states of India needs to make sure that they have strict boundary security

- For reducing the threat of Saffron Terrorism Neighboring states need to make diplomatic relations with India under regional institution (SAARC).

- For reducing the threat of Saffron terrorism neighboring states need to make economic relations with each other which will provide many benefits and would generate interdependence over each other 


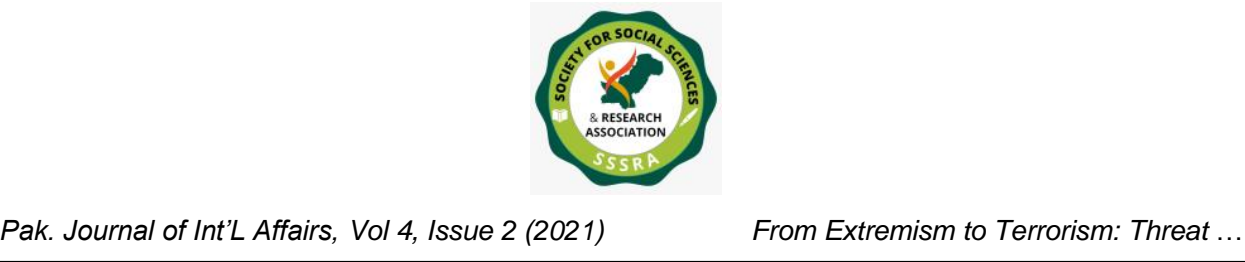

\section{REFERENCES}

(2004). The Marginalized Status Of Muslims In Gujarat: Continuing Deprivations Of Economic, Social And Cultural Rights, Six Years After The Communal Violence Of 2002 Protecting Economic, Social And Cultural Rights Of Muslims. India Second-Fifth Reporting Session Committee On Economic, Social And Cultural Rights. Retrieved from: https://www2.ohchr.org/english/bodies/cescr/docs/infongos/Gujarat_India40.pdf

(2019). Has there been no major terror attack in India since 2014? BBC News, available at: https://www.bbc.com/news/world-asia-india-46902935

(2019). Timeline of the Riots in Modi's Gujarat. Asia Pacific, Retrieved from: https://www.nytimes.com/interactive/2014/04/06/world/asia/modi-gujarat-riotstimeline.html\#/\#time287_8514

(2020). Timeline: The Rise of Narendra Modi, Reuters, Retrieved from: https://www.reuters.com/article/narendra-modi-political-career-timelineidINDEE96A0AQ20130711

Ahmed, R. (2020). Hindu Nationalism, Modi Factor and the Ideology matrix in Contemporary India. National Defence University. Retrieved from: https://ndu.edu.pk/issra/issra_pub/articles/margalla-paper/MP-2020/04-HinduNationalism.pdf

Alder, K. (2016). A short history of the rise and rise of Hindu nationalism in India. Quartz India. Retrieved from: https://qzcom.cdn.ampproject.org/v/s/qz.com/india/630144/explainer-what-are-the-originsof-todays-hindu-nationalism/

BBC News (2019). Citizenship Amendment Bill: India's new 'anti-Muslim' law explained. Retrieved from: https://www.bbc.com/news/world-asia-india$\underline{50670393}$

Britannica, T. Editors of Encyclopaedia (2021). Bharatiya Janata Party. Encyclopedia Britannica. Retrieved from: https://www.britannica.com/topic/Bharatiya-JanataParty

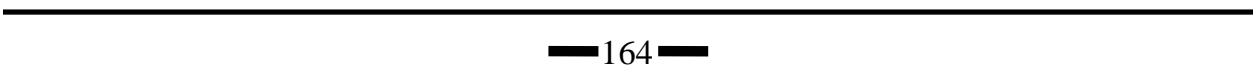


Chaudry, D. (2017). How did Hindus become Hindu and why Hindutva is not

Hinduism.Daily open to opinion, retrieved from:

https://www.dailyo.in/variety/hindu-hinduism-hindustan-

hindutva/story/1/20120.html

D'Souza, S. Mariet (2021). Narendra Modi. Encyclopedia Britannica. Retrieved from: https://www.britannica.com/biography/Narendra-Modi

Frayer, L. (2019). The Powerful Group Shaping The Rise Of Hindu Nationalism In India. NPR. Retrieved from: https://www.npr.org/2019/05/03/706808616/the-powerfulgroup-shaping-the-rise-of-hindu-in-india

Hinduism, History, available at:

https://www.history.com/topics/religion/hinduism\#: :text=Hinduism\%20is\%20th e\%20world's\%20oldest,world's\%20Hindus\%20live\%20in\%20India

Kumar. A .(2008). Bulandshahr violence | Row over photograph of riot accused with BJP leader. The News. Retrieved from:

https://www.thehindu.com/news/national/other-states/row-over-photograph-ofriot-accused-with-bjp-leader/article32125902.ece

Mag. M.(2019). Rising Hindutva \& Its Impact on The Region. International Melange Magzine, Retrieved from: https://www.melangemagazine.biz/rising-hindutva-itsimpact-on-the-region/

Narula.S . (2003). Overlooked Danger: The Security and Rights Implications of Hindu Overlooked Danger: The Security and Rights Implications of Hindu Nationalism in India Nationalism in India, Pace University, Retrieved from: https://digitalcommons.pace.edu/lawfaculty/1128/

Pande, A. (2015). Secular India vs. Hindu Nationalism, Huffington Post. Retrieved from: https://www.huffpost.com/entry/secular-india-v-hindu-nat_b_6397778

Raina, B. (2019). Citizenship Amendment Bill: A Warning Bell for the Republic, The Wire. Retrieved from: https://thewire.in/religion/citizenship-amendment-bill$\underline{\text { hindu-rashtra }}$

Rashid, Q. (2020). Narendra Modi, Akhand Bharat and "Greater India,", Future Directions International. Retrieved from: 
https://www.futuredirections.org.au/publication/narendra-modi-akhand-bharatand-greater-india/

Wagner.L. (2017). The Rise — and Fall? — of Hindu Nationalism in Nepal. Berkley Forum, Retrieved from: https://berkleycenter.georgetown.edu/responses/the-riseand-fall-of-hindu-nationalism-in-nepal 